\title{
Study of current ripple characteristics of inverter-fed multiple three-phase alternating current motors
}

\author{
Anwar Muqorobin', Pekik Argo Dahono² \\ ${ }^{1}$ Research Center for Electrical Power and Mechatronics, Badan Riset dan Inovasi Nasional, Bandung, Indonesia \\ ${ }^{2}$ School of Electrical Engineering and Informatics, Institut Teknologi Bandung, Bandung, Indonesia
}

\begin{tabular}{l} 
Article Info \\
Article history: \\
Received May 24, 2021 \\
Revised Jan 21, 2022 \\
Accepted Jan 28, 2022 \\
\hline Keywords: \\
Dual mode \\
Multiphase motor \\
Pulse width modulation \\
inverter \\
Ripple
\end{tabular}

\begin{abstract}
The need of higher power and more reliable applications have promoted the use of multiphase alternating current (AC) drives. Mostly the motors are used in wide speed operation range. To control the motors, in the low speed region the motors are operated under pulse width modulation (PWM) mode and in the high speed region, they use square wave mode. In this paper, the current ripple characteristics of inverter-fed multiple three-phase AC motors that are operated under dual mode operation (PWM and square wave modes) are investigated. The optimal motor stator winding configuration will be optimized from the viewpoint of inverter input and motor current ripples. Six-phase motor is used as the representative of even-phase motors and ninephase motor for odd-phase motors. It is found that nine-phase motor is better than six-phase motor if dual mode operation is desired. Experimental results are incorporated to support the analytical results.
\end{abstract}

This is an open access article under the CC BY-SA license.

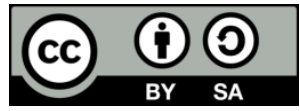

\section{Corresponding Author:}

Anwar Muqorobin

Research Center for Electrical Power and Mechatronics, Badan Riset dan Inovasi Nasional

Sangkuriang St., Bandung 40135, Indonesia

Email: anwa014@brin.go.id

\section{INTRODUCTION}

An electric motor with number of phase more than three is known as multiphase motor. Nowadays, the need of higher power and more reliable applications have promoted the use of multiphase alternating current (AC) drives, e.g. in elevator, electric ship propulsion, electric vehicle, railway traction, and turbo compressor [1]-[12]. Basically, there are only two types of multiphase motors i.e. composite phase motor and prime phase motor [13]-[15]. A composite phase motor contains some group of any phase stator winding and the most popular is multiple three-phase motor. Many research related to prime phase have been published. However, this type of motor has not been applied in industry because it needs special stator frame design. Different to that, multiple three phase motor can be built from the available three-phase stator frame design. The additional advantages is that it can be supplied by some conventional three-phase inverters and the operation under fault condition is easier. Besides that, multiple three phase motor has additional degree of freedom, i.e. the stator winding can be configured with $0^{\circ}$ phase displacement, symmetrically, or asymmetrically. For six-phase motor, the symmetrical configuration uses $60^{\circ}$ phase displacement and the asymmetrical one uses $30^{\circ}$ phase displacement. For nine-phase motor, the asymmetrical configuration uses $20^{\circ}$ phase displacement and the symmetrical one uses $40^{\circ}$ phase displacement.

The optimal configuration can be chosen in order to produce minimum inverter input current ripple, stator current ripple, rotor current ripple, and torque ripple [16]. Minimizing the input current ripple of inverter is very essential as it can extend the lifetime of the filter capacitor which is the weakest component in an inverter [17]-[19]. Minimization of stator current ripple can reduce stator copper loss, while minimum 
rotor current ripple reduces both the rotor copper loss and motor torque ripple. Rotor current ripple is more important to be considered compared to stator current ripple because the stator loss is easier to handle.

Though a lot of works have been done [15], [16], [20]-[26], it is still not clear what configuration is the best if dual mode operation is desired. Dual mode operation is important in electric vehicle and traction applications. Square wave mode is used for high speed operation and pulse width modulation (PWM) mode is used for low speed operation. The works in [15], [16] have a significant impact on the selected configuration of multiple three-phase motors applied in industry, i.e. mostly the motors are configured to be asymmetric [1]-[12]. The analysis in [15], [16] is suitable for multiphase motor operated under squarewave operation. However, mostly the motors in industry are operated under PWM mode. So, further investigation is necessary to find the optimal configuration under PWM operation.

This paper presents a study on current ripple characteristics of inverter-fed multiple three-phase AC motors that are operated under dual mode operation. The optimal configuration of the motor stator winding will be optimized from the viewpoint of inverter input and motor current ripples. For this purpose, the expressions of the current ripples in the inverter input, stator, and rotor are derived. Six-phase motor is used as the representative of even-phase motors and nine-phase motor for odd-phase motors. It is found that nine phase motor is better than six phase motor if dual mode operation is desired. To support the analysis, experimental results are included in this paper.

\section{INVERTER-FED MULTIPHASE ALTERNATING CURRENT MOTORS}

Figure 1 shows the scheme of the inverter-fed multiphase AC motor under study (nine-phase motor system is used as an example). The inverter connects the motor to a DC source. It has a large electrolytic capacitor to absorb the inverter input current ripple. From the figure, it can be seen that the system can be divided into the inverter side and the motor side. The motor has some three-phase stator winding sets with phase displacement of $\gamma$. There are two sets of three-phase stator winding in six-phase motor and three sets in nine-phase motor. The neutrals of the stator windings are isolated to each other.

There are two models for multiple three-phase motor in the literature, i.e. three-phase model extension and space vector decomposition (SVD). The three-phase extension model is useful for control development [10], [27]-[29], however this model cannot be used to describe the harmonic influence on the motor behaviour. The SVD model divides the motor into several decoupled space coordinates i.e. an $\alpha \beta$ coordinate, several $x y$ coordinates, and a zero sequence coordinate [14], [30]-[32]. A transformation matrix is required in the motor modeling. The transformation for symmetrical winding motor is different to the asymmetrical one [30], [31], [33], [34]. In this paper, transformations that can be used for motor with arbitrary phase dispacement are used [32], [35]. In a motor with distributed windings, the current harmonic sets that are passed through the air gap to produce rotor current/torque are mapped to the $\alpha \beta$ coordinate. The current harmonics in the $x y$ coordinates only circulate in the stator, resulting in additional stator copper loss.

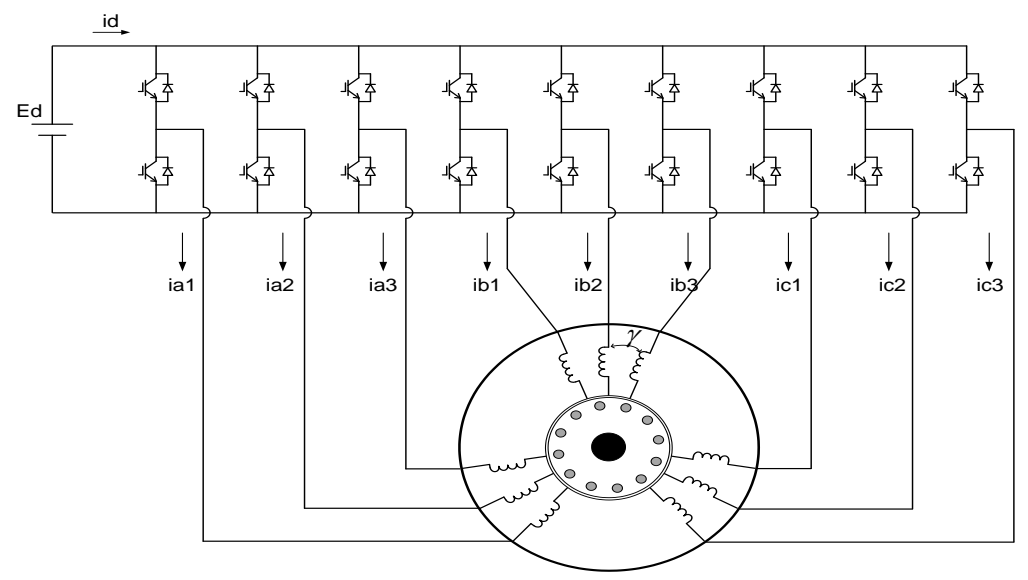

Figure 1. Inverter-fed nine-phase AC motor

\subsection{Squarewave operation}

In squarewave mode operation, the inverter legs are activated at the inverter fundamental frequency. A squarewave signal contains all odd harmonics with amplitudes that are inversely proportional to the 
harmonic order. The harmonic components can be identified by using symmetrical component theory. In a multiphase motor with distributed winding, only the first sequence set of the harmonic components that are mapped to the $\alpha \beta$ coordinate [36]. This denotes that the smaller rotor current ripple/torque pulsation can be produced from higher phase number. The analysis and experiments in [31], [37], [38] have shown that multiphase motors have smaller torque pulsation compared to three-phase motor.

For a multiple three-phase motor operating under square wave operation, it was reported that the asymmetrical configuration can give smaller rotor current ripple than the symmetrical one if the phase number is even. In odd phase motor, the symmetrical and asymmetrical configurations give similar rotor current ripple that are smaller than the zero phase displacement [15], [16]. The optimal configuration for minimizing the input current ripple is the same as the one for minimizing the rotor current ripple.

\subsection{Pulsewidth modulation operation}

Various PWM techniques can be used in inverter-fed multiple three-phase AC motor. An space vector modulation (SVM) has been proposed [39]. However, this modulation produces unwanted low order harmonics. Refinement of this modulation has been proposed to mitigate the low order harmonics [40]-[46]. The SVMs for multifrequency reference also have been proposed [46]- [49]. These SVMs techniques are intended to produce proper fundamental frequency and low order harmonics that are suitable for concentrated winding multiphase motors.

Application of carrier based modulation in multiphase inverter is purely an extension of three-phase inverter [50]. Investigation of the modulation type effect on the inverter input current ripple has been carried out. As in three-phase inverter, the modulation type does not affect the input current ripple of multiphase inverter. Moreover, the minimum ripple of DC input voltage cannot be achieved by applying zero sequence signal (ZSS) injection but can be provided by sinusoidal PWM. In addition, ZSS injection cannot minimize the output current ripple of the multiphase inverter, except on multiple three-phase inverter [51], [52]. The ZSS injection can raise the maximum modulation index. However the rise becomes smaller as the number of phase increases, e.g. $15.5 \%$ in three-phase inverter, $5.1 \%$ in five-phase inverter, $2.6 \%$ in seven-phase inverter, and become $1.5 \%$ in nine-phase inverter [53]. A composite phase number with isolated neutral points is required to achieve a high maximum modulation index.

Under PWM operation, the optimal phase number has been investigated based on motor efficiency, input current ripple and input voltage ripple. Considering the motor efficiency, the increase of phase number does not have effect on the motor efficiency reduction [54], [55]. Based on the input voltage ripple, the optimum phase number is seven [56]. This result is based on similar output power. By considering the inverter input current ripple, it is known that the optimum number of phase is nine. The number of phase more than those numbers cannot reduce the input voltage and current ripples significantly [56]. So, increasing the phase number into a high number is not always become the best solution. In addition to that, increasing the phase number can increase the control complexity.

\section{ANALYSIS OF INVERTER INPUT CURRENT RIPPLE UNDER PULSEWIDTH MODULATION OPERATION}

Inverter input current ripple can be analyzed in either frequency domain or time domain [18], [57]. The frequency domain method gives the spectrum of the input current, as a result it can be used to accurately calculate the power loss in the capacitor. However, the capacitor equivalent series resistance (ESR) has a tendency to be constant at the high frequencies. For this reason, time domain method can be used to estimate the capacitor power loss. Moreover, the time domain method gives simpler input current ripple expressions.

The input current ripple expression for six-phase inverter is:

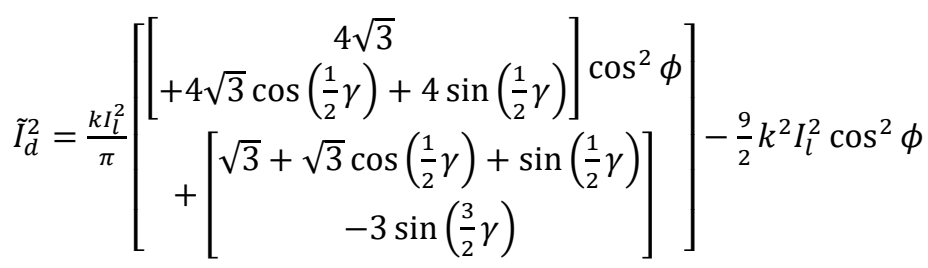

and for nine-phase inverter is: 


$$
\tilde{I}_{d}^{2}=\frac{k I_{l}^{2}}{\pi}\left[\begin{array}{c}
{\left[\begin{array}{c}
6 \sqrt{3}+8 \sqrt{3} \cos \left(\frac{1}{2} \gamma\right)+8 \sin \left(\frac{1}{2} \gamma\right) \\
+4 \sqrt{3} \cos (\gamma)+4 \sin (\gamma)
\end{array}\right] \cos ^{2} \phi} \\
+\left[\begin{array}{c}
\frac{3}{2} \sqrt{3}+2 \sqrt{3} \cos \left(\frac{1}{2} \gamma\right)+2 \sin \left(\frac{1}{2} \gamma\right) \\
+\sqrt{3} \cos (\gamma)+\sin (\gamma) \\
-3 \sin (3 \gamma)-6 \sin \left(\frac{3}{2} \gamma\right)
\end{array}\right]
\end{array}\right]-\frac{81}{8} k^{2} I_{l}^{2} \cos ^{2} \phi
$$

where $\tilde{I}_{d}$ is the input current ripple, $k$ is the modulation index, $I_{l}$ is the load current (rms), and $\phi$ is the power factor angle. The detail of the current ripples derivation can be found in [57].

The optimal configuration can be obtained by differentiating (1) and (2) with respect to phase displacement $\gamma$. The current ripples (1) and (2) are evaluated using three phase displacements, those are zero phase displacement, asymmetrical configuration, and symmetrical configuration for power factor of 1.0 and 0.8, as shown in Figure 2 (a), Figure 2 (b), Figure 3 (a), and Figure 3 (b). Figures 2 and 3 show that the maximum current ripple is given by zero phase displacement, the asymmetrical configuration provides middle input current ripple, and the minimum current ripple is given by the symmetrical configuration.

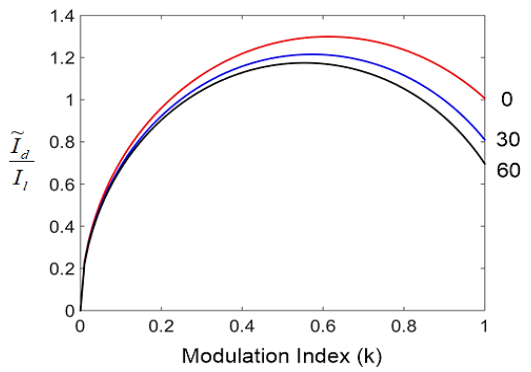

(a)

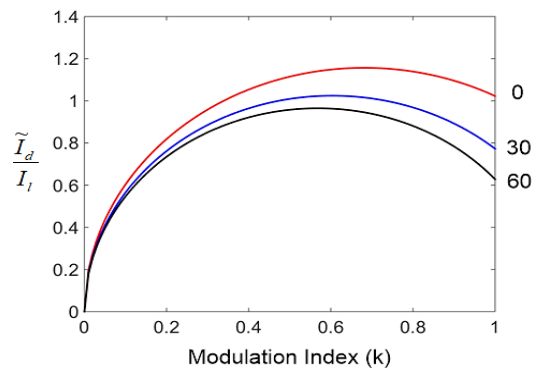

(b)

Figure 2. Calculated input current ripples of six-phase inverter (a) power factor of 1.0 and (b) power factor of 0.8

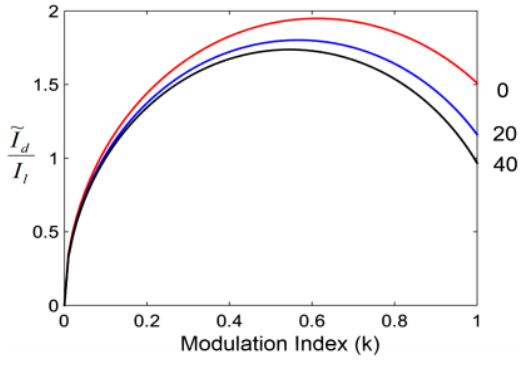

(a)

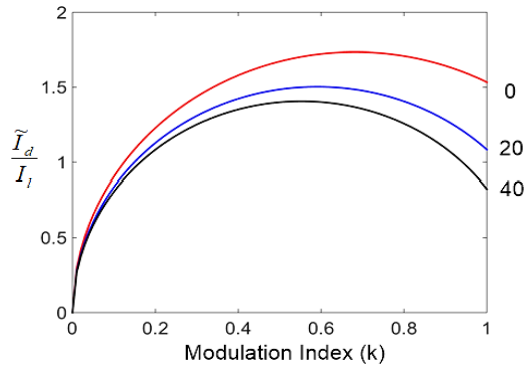

(b)

Figure 3. Calculated input current ripple of nine-phase inverter (a) power factor of 1.0 and (b) power factor of 0.8

\section{ANALYSIS OF MOTOR CURRENT RIPPLE UNDER PULSEWIDTH MODULATION OPERATION}

To analyze the motor current ripple, the motor model in the stationary reference frame is used. The motor current ripple in each coordinate is expressed as integration of each stator voltage ripple [41].

$$
\begin{aligned}
& \tilde{\imath}_{\alpha \beta s} \approx \frac{1}{\sigma L_{s}} \int \tilde{v}_{\alpha \beta s} d t \\
& \tilde{l}_{x y s} \approx \frac{1}{L_{l s}} \int \tilde{v}_{x y s} d t
\end{aligned}
$$

Where $\tilde{\imath}_{\alpha \beta s}, \tilde{\imath}_{x y s}, \tilde{v}_{\alpha \beta s}$, and $\tilde{v}_{x y s}$, are the current ripples in the $\alpha \beta$ coordinate, current ripples in the $x y$ coordinates, voltage ripples in the $\alpha \beta$ coordinate, and voltage ripples in the xy coordinates. We can approximate the value of $\sigma L_{s}$ by the summation of the stator leakage inductance $L_{l s}$ and the rotor leakage inductance $L_{l r}$ is being as: 


$$
\sigma L_{s} \approx L_{l s}+L_{l r}
$$

The rotor current ripple can be predicted from the current ripple in the $\alpha \beta$ coordinate. The stator current ripple is resulted from the summation of the current ripple in the $\alpha \beta$ coordinate and the current ripple in the $x y$ coordinate. The stator leakage inductance is lower than $\sigma L_{s}$, therefore, the stator current ripple is much influenced by the current ripple in the $x y$ coordinate rather than the current ripple in the $\alpha \beta$ coordinate. The detail of the motor current ripple derivation can refer to [35]. The current ripple in the $\alpha \beta$ coordinate of sixphase motor is in (6) and the current ripple in the $x y$ coordinate is in (7). The current ripple of nine-phase motor in the $\alpha \beta$ coordinate is in (8) and the current ripple in the $x y$ coordinate is in (9). In (6)-(9) are based on time domain analysis. Besides that, we can also refer to [58] for the frequency domain analysis, but this is not the scope of this paper.

$$
\begin{aligned}
& \tilde{I}_{\alpha \beta r m s}^{2}=K_{\alpha \beta}^{2}\left[\frac{3}{2} k^{4}+\frac{1}{\pi}\left[\begin{array}{c}
-\frac{8}{3} \sqrt{3} \\
\frac{8}{9} \sqrt{3} \cos \left(\frac{5}{2} \gamma\right)-\frac{8}{9} \sin \left(\frac{5}{2} \gamma\right) \\
+\frac{8}{3} \sin \left(\frac{3}{2} \gamma\right) \\
-\frac{32}{9} \sqrt{3} \cos \left(\frac{1}{2} \gamma\right)-\frac{32}{9} \sin \left(\frac{1}{2} \gamma\right)
\end{array}\right] k^{3}+2 k^{2}\right] \\
& \tilde{I}_{x y r m s}^{2}=K_{x y}^{2} \frac{1}{\pi}\left[\begin{array}{c}
-\frac{8}{3} \sqrt{3} \\
-\frac{8}{9} \sqrt{3} \cos \left(\frac{5}{2} \gamma\right)+\frac{8}{9} \sin \left(\frac{5}{2} \gamma\right) \\
-\frac{8}{3} \sin \left(\frac{3}{2} \gamma\right) \\
+\frac{32}{9} \sqrt{3} \cos \left(\frac{1}{2} \gamma\right)+\frac{32}{9} \sin \left(\frac{1}{2} \gamma\right)
\end{array}\right] k^{3} \\
& \tilde{I}_{\alpha \beta r m s}^{2}=K_{\alpha \beta}^{2}\left[\frac{3}{2} k^{4}+\frac{1}{\pi}\left[\begin{array}{c}
-\frac{16}{9} \sqrt{3} \\
+\frac{32}{27} \sin (3 \gamma)+\frac{64}{27} \sin \left(\frac{3}{2} \gamma\right) \\
+\frac{32}{81} \sqrt{3} \cos (5 \gamma)-\frac{32}{81} \sin (5 \gamma) \\
+\frac{64}{81} \sqrt{3} \cos \left(\frac{5}{2} \gamma\right)-\frac{64}{81} \sin \left(\frac{5}{2} \gamma\right) \\
-\frac{128}{81} \sqrt{3} \cos (\gamma)-\frac{128}{81} \sin (\gamma) \\
-\frac{256}{81} \sqrt{3} \cos \left(\frac{1}{2} \gamma\right)-\frac{256}{81} \sin \left(\frac{1}{2} \gamma\right)
\end{array}\right] k^{3}+2 k^{2}\right] \\
& \tilde{I}_{x y r m s}^{2}=K_{x y}^{2} \frac{1}{\pi}\left[\begin{array}{c}
-\frac{32}{9} \sqrt{3} \\
-\frac{32}{27} \sin (3 \gamma)-\frac{64}{27} \sin \left(\frac{3}{2} \gamma\right) \\
-\frac{32}{81} \sqrt{3} \cos (5 \gamma)+\frac{32}{81} \sin (5 \gamma) \\
-\frac{64}{81} \sqrt{3} \cos \left(\frac{5}{2} \gamma\right)+\frac{64}{81} \sin \left(\frac{5}{2} \gamma\right) \\
+\frac{128}{81} \sqrt{3} \cos (\gamma)+\frac{128}{81} \sin (\gamma) \\
+\frac{256}{81} \sqrt{3} \cos \left(\frac{1}{2} \gamma\right)+\frac{256}{81} \sin \left(\frac{1}{2} \gamma\right)
\end{array}\right] k^{3}
\end{aligned}
$$

where $K_{\alpha \beta}^{2}=\frac{1}{256} \frac{1}{3}\left(\frac{E_{d}}{f_{s} \sigma L_{s}}\right)^{2}, K_{x y}^{2}=\frac{1}{256} \frac{1}{3}\left(\frac{E_{d}}{f_{s} L_{l s}}\right)^{2}, f_{s}$ is the switching frequency, and $E_{d}$ is the DC input voltage.

In (6) is plotted in Figure 4 (a) and (7) is plotted in Figure 4 (b). Meanwhile (8) and (9) are plotted in Figures 5 (a) and 5 (b), respectively. Figures 4 and 5 show that the largest current ripple in the $\alpha \beta$ coordinate is given by zero phase displacement. The nonzero phase displacement can reduce this current ripple and the lowest is given by the symmetrical configuration. Theoretically, zero phase displacement does not give current ripple in the $x y$ coordinate. This means all the stator current harmonic components are passed to the rotor. Therefore, multiple three-phase motor with zero phase displacement has similar characteristics to three-phase motor. From Figures 4 (b) and 5 (b), symmetrical configurations produce the highest current ripple in the $x y$ coordinate and also the stator current ripple. Though the symmetrical configuration produces the highest current ripple in the stator, this ripple can be minimized by using third 
harmonic injection that is commonly used for three-phase inverter [59]. For multiphase inverter, this harmonic injection is useful only for multiple three phase inverter [52].

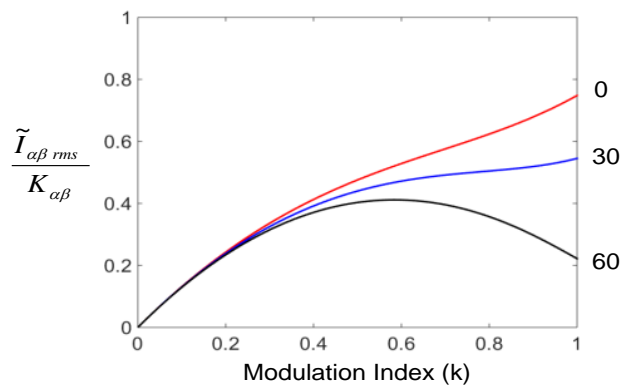

(a)

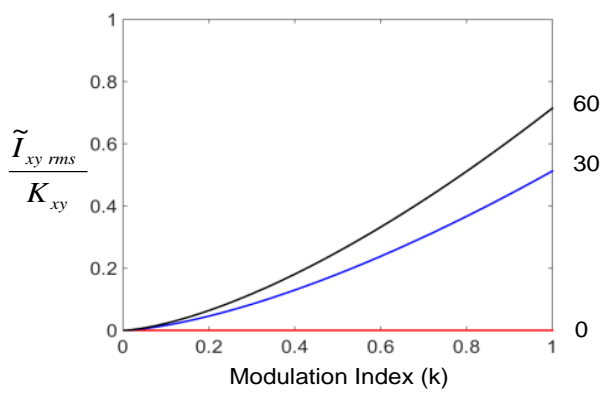

(b)

Figure 4. Calculated current ripples of six-phase motor (a) in the $\alpha \beta$ coordinate and (b) in the $x y$ coordinate

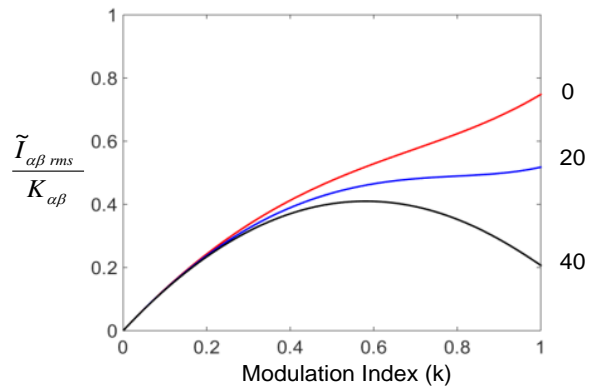

(a)

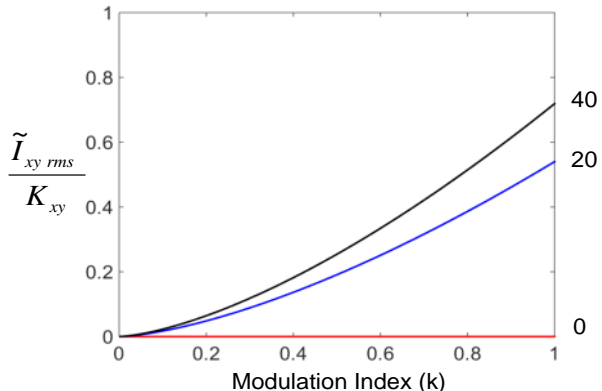

(b)

Figure 5. Calculated current ripples of nine-phase motor (a) in the $\alpha \beta$ coordinate and (b) in the $x y$ coordinate

\section{RESULTS AND DISCUSSION}

\subsection{Optimal configuration for dual mode operation}

The previous analyses have presented the inverter input current and motor current ripples. The current ripple characteristics are summarized in Tables 1 and 2. As stated in the introduction, the optimal configuration is one that produces minimum current ripples in both the inverter input and the rotor. From Table 1, it is known that the optimal configuration of six-phase motor under squarewave operation is the asymmetrical one. However, under PWM operation, the optimum configuration is symmetric. It means sixphase motor is not worthy for dual mode operation. Table 2 shows that nine-phase motor can be considered as a better option for dual mode operation since its symmetrical configuration provides optimum characteristics under PWM and squarewave operations. In general, the right motor is an odd multiple threephase motor with symmetrical configuration. The general equation of $n$-phase inverter input current ripple under PWM operation is:

$$
\tilde{I}_{d}^{2}=\frac{k l_{l}^{2}}{\pi}\left[\begin{array}{c}
{\left[\frac{2 n}{3} \sqrt{3}+\sum_{m=1}^{\frac{n}{3}-1} 4 m\left(\sqrt{3} \cos \left(\left(\frac{n}{3}-m\right) \frac{\gamma}{2}\right)+\sin \left(\left(\frac{n}{3}-m\right) \frac{\gamma}{2}\right)\right)\right] \cos ^{2} \phi} \\
\frac{n}{3} \frac{\sqrt{3}}{2}+ \\
+\left[\begin{array}{c}
\frac{n}{3}-1 \\
\sum_{m=1}^{3} m\left(\sqrt{3} \cos \left(\left(\frac{n}{3}-m\right) \frac{\gamma}{2}\right)+\sin \left(\left(\frac{n}{3}-m\right) \frac{\gamma}{2}\right)\right)-\sum_{m=1}^{\frac{n}{3}-1}(n-3 m) \sin \left(\frac{3}{2} m \gamma\right)
\end{array}\right] \\
-\frac{n^{2}}{8} k^{2} I_{l}^{2} \cos ^{2} \phi
\end{array}\right]
$$

The general equation of the motor current ripple in the $\alpha \beta$ coordinate is: 


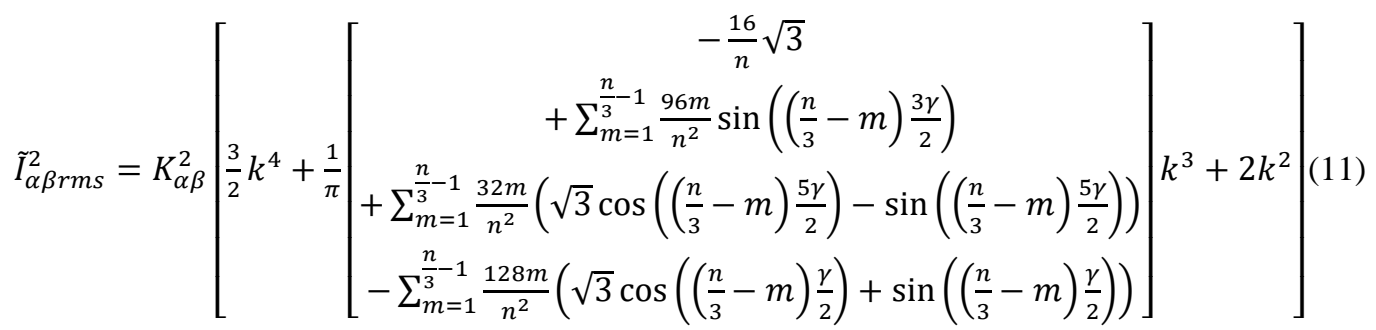

The general equation of the motor current ripple in the $x y$ coordinate is:

$$
\tilde{I}_{x y r m s}^{2}=K_{x y}^{2} \frac{1}{\pi}\left[\begin{array}{c}
-\frac{16(n-3)}{3 n} \sqrt{3} \\
-\sum_{m=1}^{\frac{n}{3}-1} \frac{96 m}{n^{2}} \sin \left(\left(\frac{n}{3}-m\right) \frac{3 \gamma}{2}\right) \\
-\sum_{m=1}^{\frac{n}{3}-1} \frac{32 m}{n^{2}}\left(\sqrt{3} \cos \left(\left(\frac{n}{3}-m\right) \frac{5 \gamma}{2}\right)-\sin \left(\left(\frac{n}{3}-m\right) \frac{5 \gamma}{2}\right)\right) \\
+\sum_{m=1}^{\frac{n}{3}-1} \frac{128 m}{n^{2}}\left(\sqrt{3} \cos \left(\left(\frac{n}{3}-m\right) \frac{\gamma}{2}\right)+\sin \left(\left(\frac{n}{3}-m\right) \frac{\gamma}{2}\right)\right)
\end{array}\right] k^{3}
$$

By inserting the phase number $n$ in (10)-(12) and differentiating with respect to the phase displacement $\gamma$, we will get the optimal configuration for the related phase number.

Table 1. Six-phase motor characteristics

\begin{tabular}{ccccc}
\hline Six-phase & Current Ripples & $0^{\circ}$ & $30^{\circ}$ & $60^{\circ}$ \\
\hline Squarewave & Input & Max & Min & Max \\
& Stator & Min & Max & Min \\
& Rotor & Max & Min & Max \\
PWM & Input & Max & & Min \\
& Stator & Min & & Max \\
& Rotor & Max & & Min \\
\hline
\end{tabular}

Table 2. Nine-phase motor characteristics

\begin{tabular}{ccccc}
\hline Six-phase & Current Ripples & $0^{\circ}$ & $20^{\circ}$ & $40^{\circ}$ \\
\hline Squarewave & Input & Max & Min & Min \\
& Stator & Min & Max & Max \\
& Rotor & Max & Min & Min \\
PWM & Input & Max & & Min \\
& Stator & Min & & Max \\
& Rotor & Max & & Min \\
\hline
\end{tabular}

\subsection{Experimental results}

Experiments were conducted to evidence the effect of motor configuration on the inverter input and motor current ripples. The experimental setup is shown in Figure 6. The switching components are IRFP460 with TLP250 used as the gate driver and opto-isolator. The squarewave and PWM algorithms are embedded in an FPGA Altera DE2-70. The motor parameters are shown in Table 3 and Table 4, each is for six-phase motors and nine-phase motors, respectively. The inverter input is set to a constant value of $40 \mathrm{Vdc}$. The frequency of $50 \mathrm{~Hz}$ is used for the inverter fundamental frequency. In order to eliminate the effects of motors Electromotive Force in the calculation, the rotors were locked during the experiments. A digital oscilloscope is used to record the current waveforms.

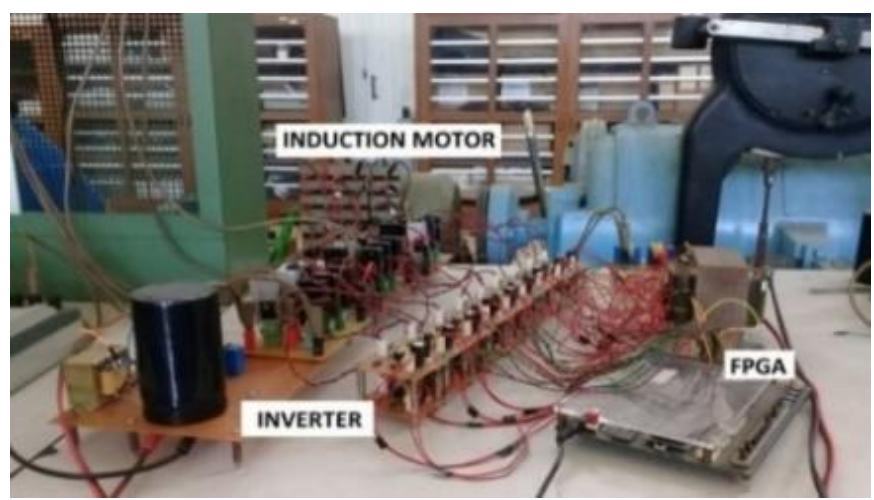

Figure 6. Experimental setup 
Table 3. Six-phase motor parameters

\begin{tabular}{lc}
\hline \multicolumn{1}{c}{ Parameter } & Value \\
\hline Rotor resistance & $1.25 \Omega$ \\
Stator resistance & $1.25 \Omega$ \\
Rotor leakage inductance & $4.85 \mathrm{mH}$ \\
Stator leakage inductance & $5.2 \mathrm{mH}$ \\
Magnetizing inductance & $40.93 \mathrm{mH}$ \\
Number of poles & 4 \\
Nominal power & $3 \mathrm{HP}$ \\
Nominal current & $8.3 \mathrm{~A}$ \\
\hline
\end{tabular}

Table 4. Nine-phase motor parameters

\begin{tabular}{lc}
\hline \multicolumn{1}{c}{ Parameter } & Value \\
\hline Rotor resistance & $0.86 \Omega$ \\
Stator resistance & $0.92 \Omega$ \\
Rotor leakage inductance & $4.64 \mathrm{mH}$ \\
Stator leakage inductance & $5.40 \mathrm{mH}$ \\
Magnetizing inductance & $160 \mathrm{mH}$ \\
Number of poles & 4 \\
Nominal power & $7.5 \mathrm{HP}$ \\
Nominal current & $11.3 \mathrm{~A}$ \\
\hline
\end{tabular}

\subsubsection{Experimental results of squarewave operation}

The input current of squarewave six-phase inverters are shown in Figures 7 (a)-(c). The figures show that the asymmetrical configuration provides minimum current ripple in the inverter input. The symmetrical configuration and zero phase displacement have equal input current ripple. In addition, the frequency of the input current ripple of the asymmetrical configuration is higher (twelve times of the fundamental frequency). Therefore, this is an additional benefit of the asymmetrical configuration in addition to the minimum rotor current and torque ripples. Experiments of squarewave operation of nine-phase inverters also have been conducted. The input currents can be seen in Figure 8 (a) and Figure 8 (b). The figure shows that the symmetrical configuration gives similar input current ripple to the asymmetrical one.

The stator currents of six-phase motors under squarewave operation can be seen in Figure 9 (a)-(c). After all the phase currents are measured, transformation into $\alpha \beta$ coordinate is conducted. The currents in the $\alpha \beta$ coordinate are presented in Figures 10 (a)-(c). The figures show that the asymmetrical configuration produces minimum current ripple in the $\alpha \beta$ coordinate, but the stator current ripple become larger. The stator currents of nine-phase motors under squarewave operation are shown in Figure 11 (a) and Figure 11 (b) and the currents in the $\alpha \beta$ coordinate are presented in Figure 12 (a) and Figure 12 (b). The figures show that the stator current ripple and current ripple in the $\alpha \beta$ coordinate of the motor with symmetrical configuration are similar to those of the motor with asymmetrical configuration.

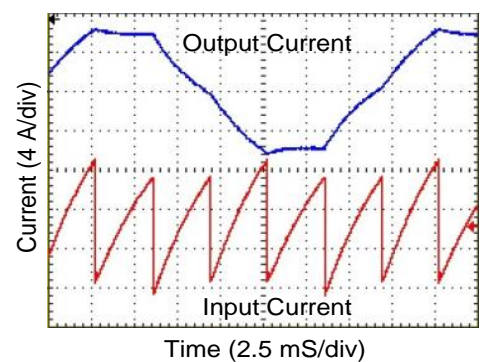

(a)

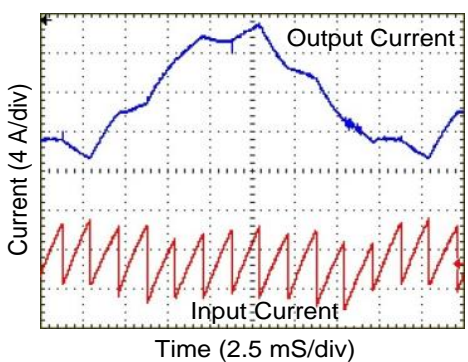

(b)

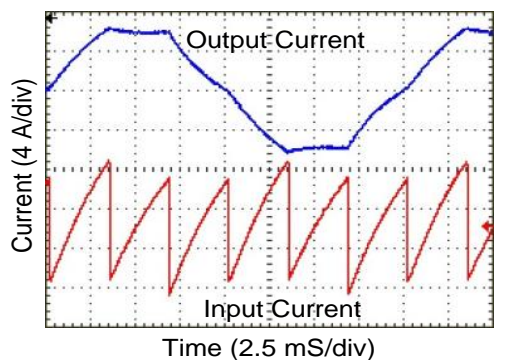

(c)

Figure 7. Input currents of six-phase inverters (Ampere/div $=4 \mathrm{~A}$; time/div $=2.5 \mathrm{~ms}$ ) (a) zero phase displacement, (b) asymmetrical configuration, and (c) symmetrical configuration

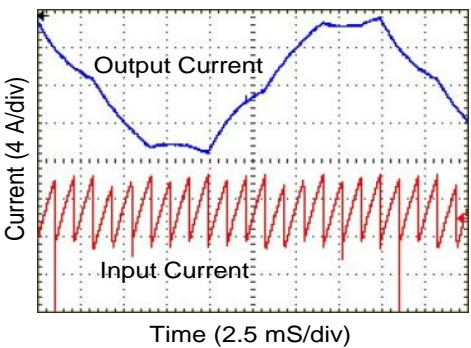

(a)

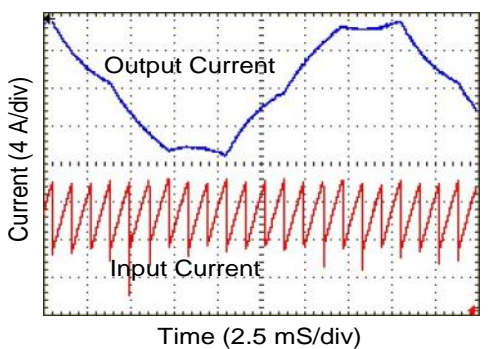

(b)

Figure 8. Input currents of nine-phase inverters (Ampere/div $=4 \mathrm{~A}$; time/div $=2.5 \mathrm{~ms}$ ) (a) asymmetrical and (b) symmetrical configurations 


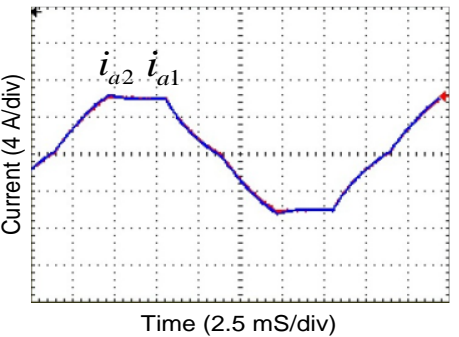

(a)

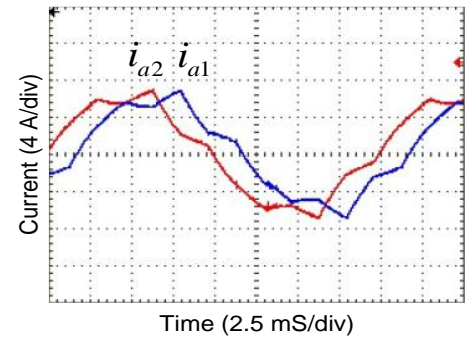

(b)

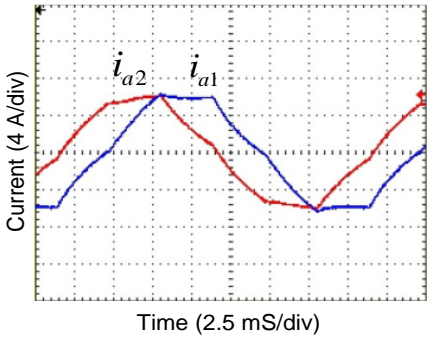

(c)

Figure 9. Stator currents of six-phase motors (Ampere/div=4 A; time/div=2.5 ms), (a) zero phase displacement, (b) asymmetrical configuration, and (c) symmetrical configuration

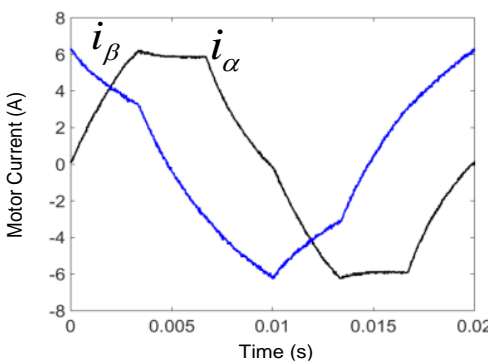

(a)

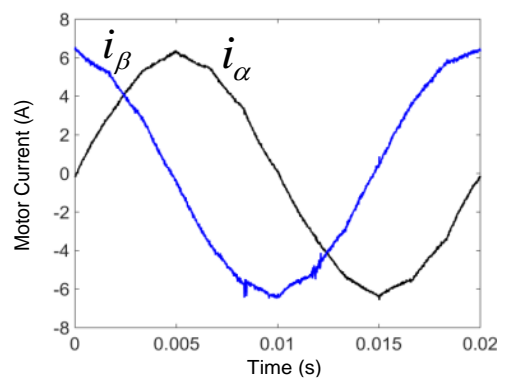

(b)

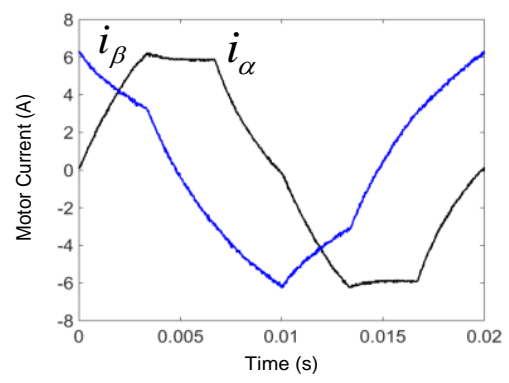

(c)

Figure 10. The six-phase motors currents in the $\alpha \beta$ coordinate (a) zero phase displacement, (b) asymmetrical, and (c) symmetrical configurations

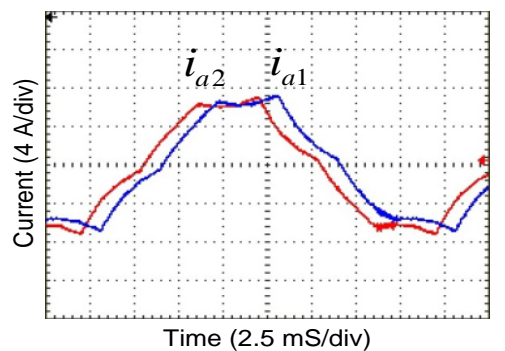

(a)

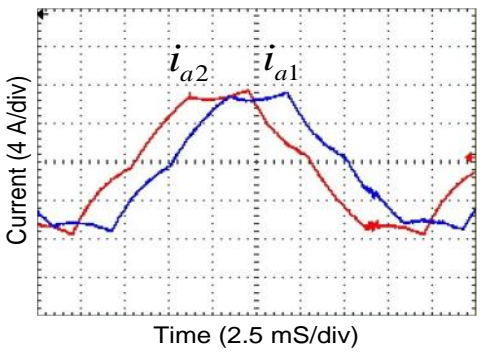

(b)

Figure 11. Stator currents of nine-phase motors (Ampere/div $=4 \mathrm{~A}$; time/div $=2.5 \mathrm{~ms}$ ) (a) asymmetrical configuration and (b) symmetrical configuration

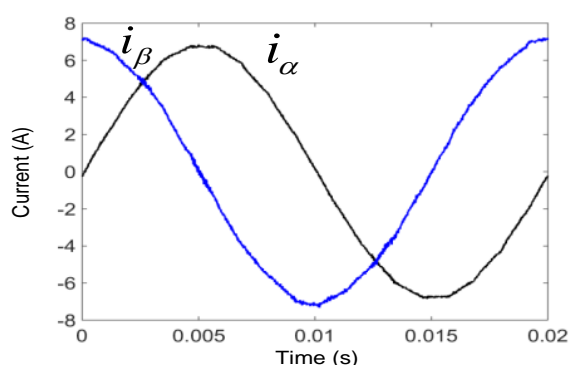

(a)

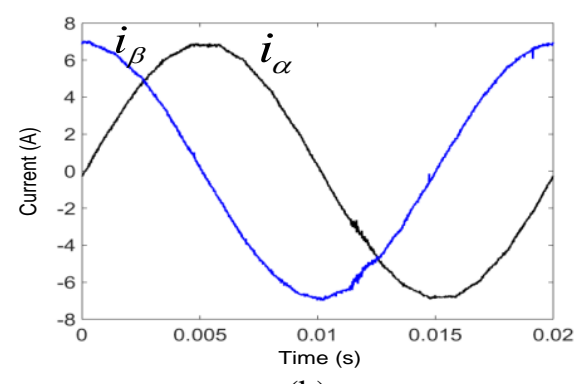

(b)

Figure 12. The nine-phase motors currents in the $\alpha \beta$ coordinate (a) asymmetrical configuration and (b) symmetrical configuration 


\subsubsection{Experimental results of inverter input current ripples under pulsewidth modulation operation}

During the experiments of PWM operation, $1 \mathrm{kHz}$ carrier frequency is used. The input current of six-phase inverter and the stator current are presented in Figures 13(a)-(c). At these figures, the modulation indexes are one. From Figure 13, it is known that the stator currents are almost perfect sinusoidal. These figures also show that the symmetrical configuration results in the lowest current ripple in the inverter input. The inverter input current ripples as function of modulation indexes are shown in Figure 14. From the figures, the agreement between the results of calculations and experiments can be appreciated.

The experimental results of nine-phase inverter are shown in Figure 15(a) and Figure 15(b). The modulation indexes are also one at those waveforms. Figure 15(a) and Figure 15(b) clearly show that the symmetrical configuration gives lower inverter input current ripple compared to the asymmetrical one. Figure 16 shows the calculation and measurement results of the inverter input current ripples as a function of the modulation indexes. The validity of the input current ripple calculation can be appreciated from this figure.

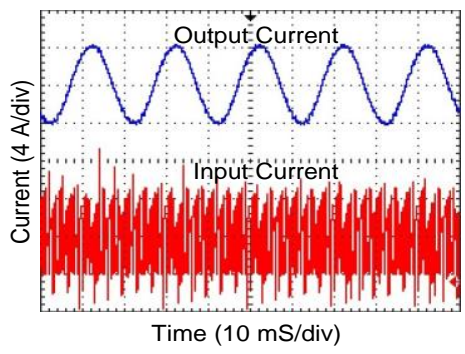

(a)

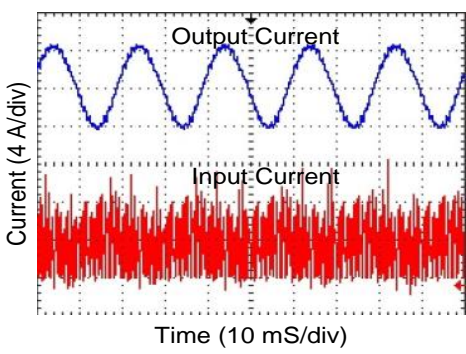

(b)

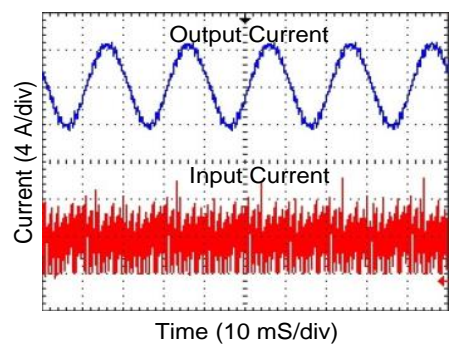

(c)

Figure 13. Input currents of six-phase inverters (Ampere/div $=4 \mathrm{~A}$; time/div $=10 \mathrm{~ms}$ ) (a) zero phase displacement, (b) asymmetrical configuration, and (c) symmetrical configuration

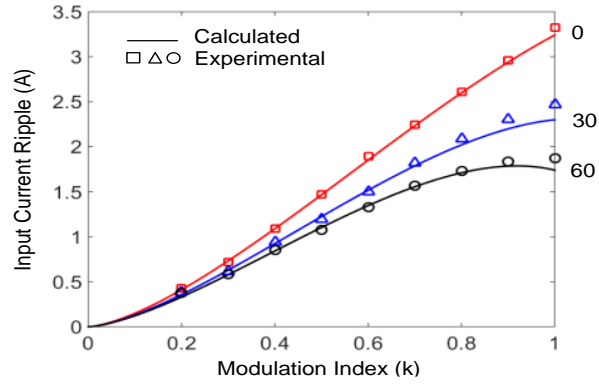

Figure 14. Six-phase inverters input current ripples

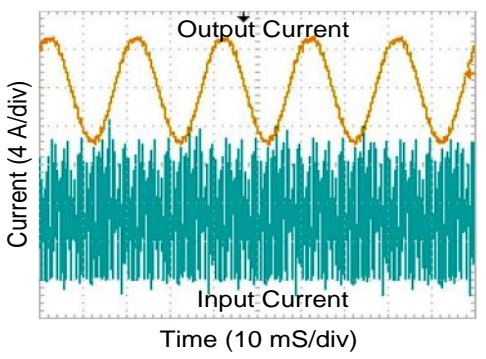

(a)

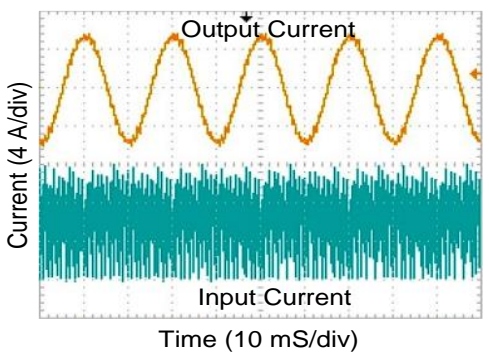

(b)

Figure 15. Output current of phase a1 and input current of nine-phase PWM inverters (Ampere/div = $4 \mathrm{~A}$; time/div $=10 \mathrm{~ms}$ ) (a) asymmetrical configuration and (b) symmetrical configuration 


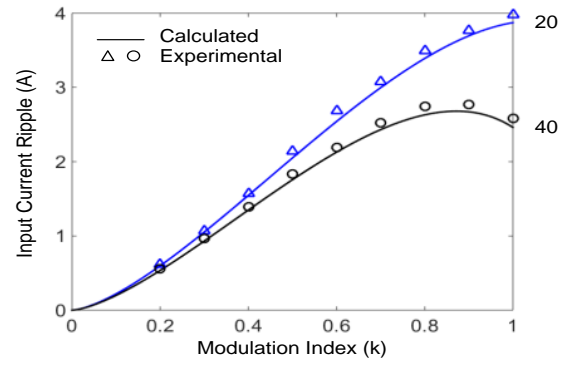

Figure 16. Nine-phase inverter input current ripples

\subsubsection{Experimental results of motor current ripples under pulsewidth modulation operation}

The stator currents of six-phase motors are shown in Figures 17(a)-(c). The modulation indexes that are used are one. It is known from the figures that the minimum stator current ripple is given by zero phase displacement and the maximum is provided by the symmetrical configuration. The currents in the $\alpha \beta$ coordinate are shown in Figures 18(a)-(c). The figures show that zero phase displacement gives the highest current ripple and the minimum is provided by the symmetrical configuration.

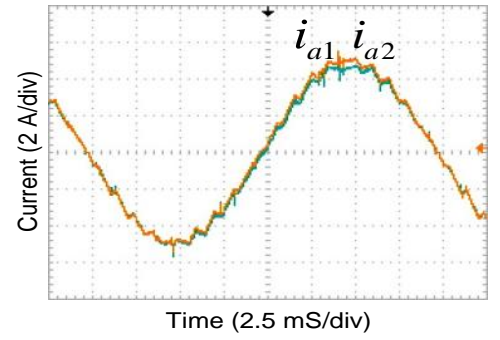

(a)

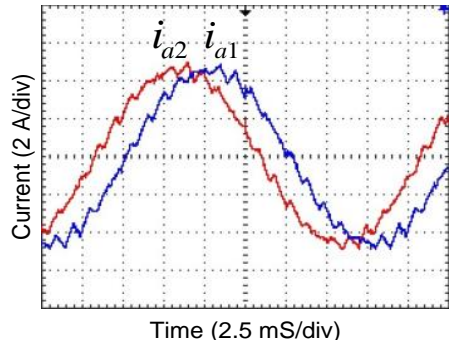

(b)

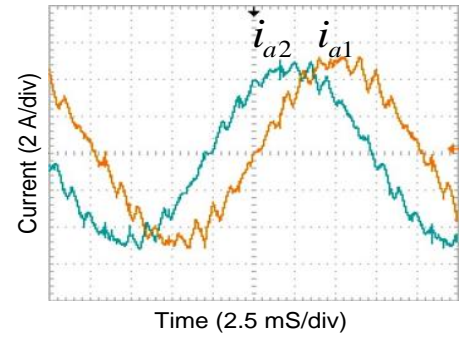

(c)

Figure 17. Stator currents of six-phase motors (Ampere/div $=2 \mathrm{~A}$; time/div $=2.5 \mathrm{~ms}$ ), (a) zero phase displacement, (b) asymmetrical configuration, and (c) symmetrical configuration

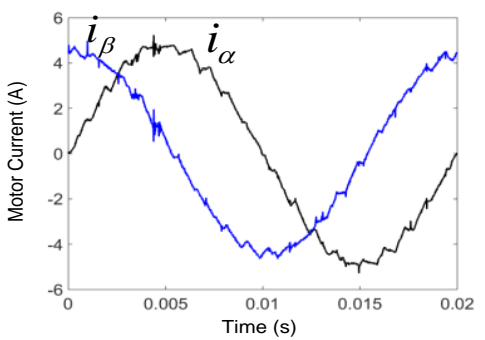

(a)

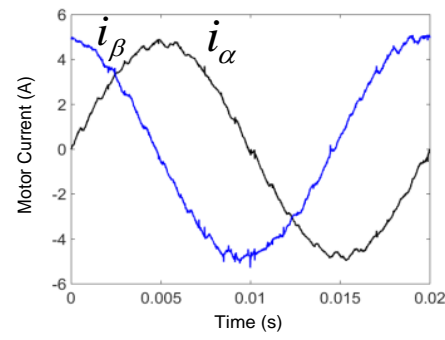

(b)

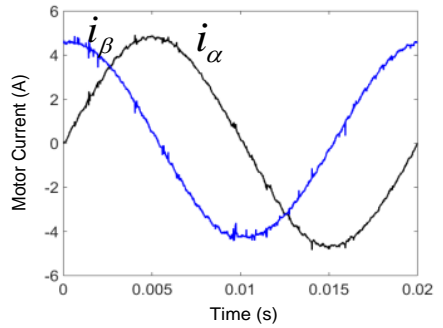

(c)

Figure 18. Six-phase motors currents in the $\alpha \beta$ coordinate (a) zero phase displacement, (b) asymmetrical configuration, and (c) symmetrical configuration

The waveform of the stator current is passed to a high pass filter (HPF) to obtain the ripple component. The HPF cut-off frequency is chosen to be lower than the switching frequency and higher than the fundamental frequency. In this study we uses cut-off frequency of $450 \mathrm{~Hz}$. The rms of the filtered signal (current ripple) can be easily obtained by using PSIM software. The rms of the motor current ripples are shown in Figure 19 (a) and Figure 19 (b). From Figure 19 (a), we can see that the $\alpha \beta$ coordinate current ripple of the zero phase displacement motor is in agreement with the prediction. Current ripple in the $x y$ coordinates in Figure 19 (b) can occur due to system imbalances, such as in stator windings and switching delays in power semiconductors. The agreement between the calculation and experimental results of the asymmetrical six-phase motor can be seen in both $\alpha \beta$ and $x y$ coordinates. In the case of the symmetrical sixphase motor, the agreement in the $x y$ coordinate can also be appreciated. The difference between the 
calculation results and the measurement results lies in the $\alpha \beta$ coordinates. However, the measured current ripples are still close to the predicted value. This difference could be resulted from the motor parameter variation during the measurement process. From Figures 17 and 18 we can see the appearance of noise in the captured signals, however the noise is quite small and does not obscure the main information from the captured signals.

Figure 20 shows the stator current ripples of six-phase motors as function of modulation indexes. From Figure 20 and also Figure 19 (b), it is known that the stator current ripples are strongly influenced by the current ripples in the $x y$ coordinate. The highest stator current ripple is given by the symmetrical configuration and then followed by the asymmetrical configuration. Zero phase displacement motor has smallest stator current ripple because theoretically it has no current ripple in the $x y$ coordinate.

The measured stator currents of nine-phase motors are presented in Figures 21 (a) and (b) and the currents in the $\alpha \beta$ coordinate can be seen in Figures 22 (a) and 22 (b). From Figures 21 (a) and (b), it is not so clear the difference of the current ripple between the symmetrical and the asymmetrical motors, however Figures 22 (a) and (b) show clearly that the current ripple in the $\alpha \beta$ coordinate of the symmetrical motor is lower than the asymmetrical motor. The rms values of motor current ripples as function of modulation indexes can be seen in Figure 23 (a), Figure 23 (b), and Figure 24. These figures show that the calculations and experiments are in a good agreement. Similar to Figures 19 (b) and 20, Figures 23 (b) and 24 also show that the current ripples in the $x y$ coordinate have a large effect on the stator current ripples. The highest stator current ripples are also given by the symmetrical configuration.

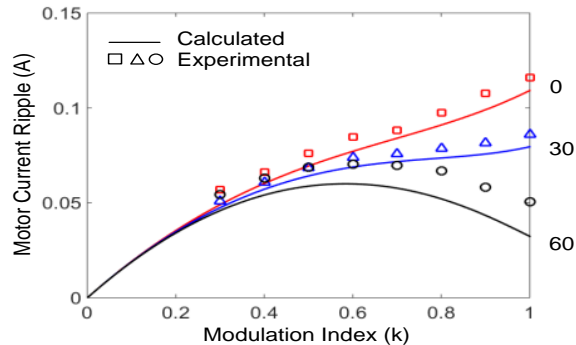

(a)

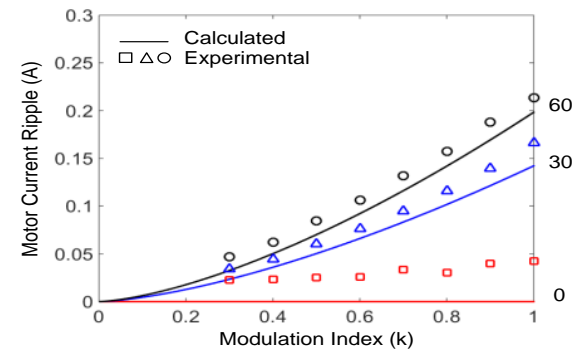

(b)

Figure 19. Six-phase motors current ripples, (a) in the $\alpha \beta$ coordinate and (b) in the $x y$ coordinate

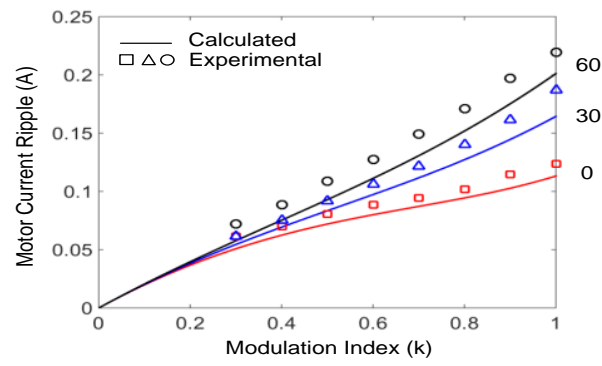

Figure 20. Six-phase motors stator current ripples

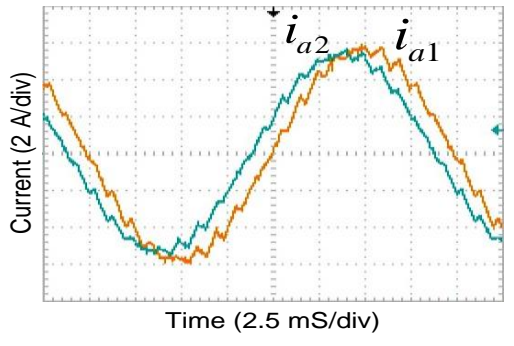

(a)

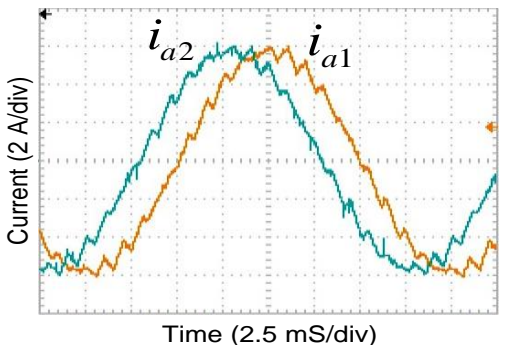

(b)

Figure 21. Stator currents of nine-phase motors (Ampere/div $=2 \mathrm{~A}$; time/div $=2.5 \mathrm{~ms}$ ) (a) asymmetrical configuration and (b) symmetrical configuration 


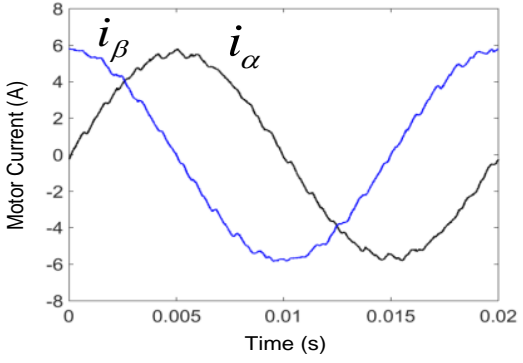

(a)

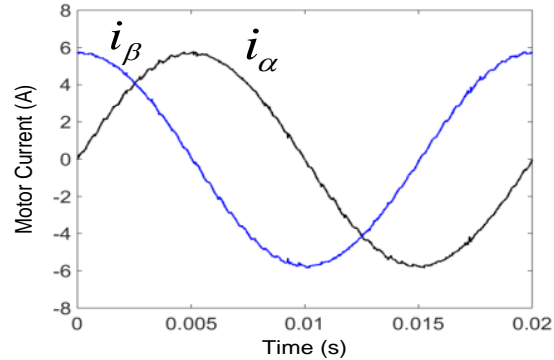

(b)

Figure 22. Nine-phase motors currents in the $\alpha \beta$ coordinate of (a) asymmetrical configuration and (b) symmetrical configuration

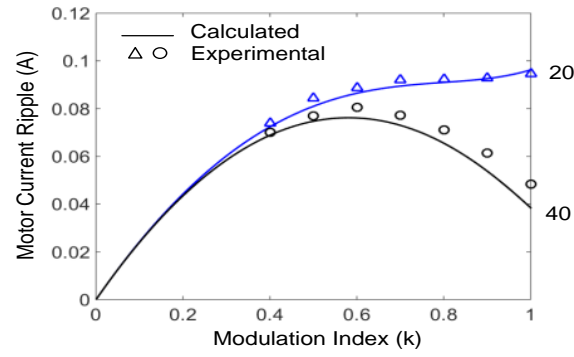

(a)

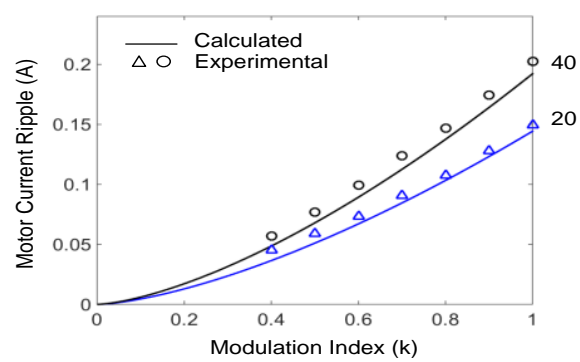

(b)

Figure 23. Nine-phase motors current ripples (a) in the $\alpha \beta$ coordinate and (b) in the $x y$ coordinate

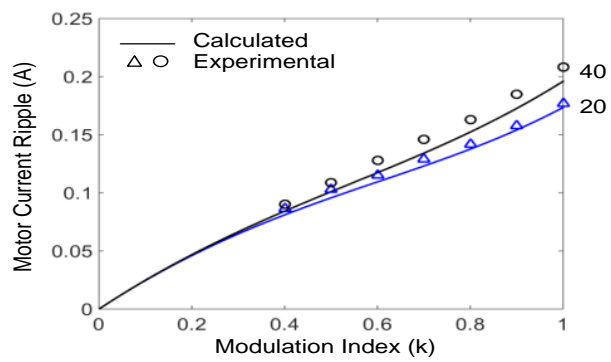

Figure 24. Nine-phase motors stator current ripples

\section{CONCLUSION}

A study on current ripple characteristics of inverter-fed multiple three-phase motor operated under dual mode operation has been presented. Experiments are conducted to verify the analysis. From the analysis and experimental results, we can observe the optimum configuration for the motor. Under squarewave operation, the optimal configuration for six-phase motor is asymmetical configuration. However, under PWM operation, the optimum configuration is the symmetrical one. As a result, six phase motor is not worthy for dual mode operation. For nine-phase motor, both the symmetrical and asymmetrical configurations give similar current ripple characteristics and both are optimal compared to the zero phase displacement. Investigation of nine-phase motor under PWM operation showed that the optimal is the symmetical configuration. From this, we can conclude that symmetrical nine-phase motor provides optimum current ripple characteristics under dual mode operation. Furthermore we can generalize that the optimal multiphase motor for dual mode operation is an odd multiple three-phase motor with symmetrical configuration.

\section{ACKNOWLEDGEMENTS}

The authors wish to thank School of Electrial Engineering and Informatics, Institut Teknologi Bandung (ITB), for providing experimental facility. 


\section{REFERENCES}

[1] G. K. Singh, "Multi-phase induction machine drive research-a survey," Electric Power Systems Research, vol. 6, no. 2, pp. 139-147, March 2002, doi: 10.1016/S0378-7796(02)00007-X.

[2] F. F. Nouvion, "Three-Phase Motors in Electric Rail Traction,” in IEEE Transactions on Industry Applications, vol. IA-20, no. 5, pp. 1152-1170, Sept. 1984, doi: 10.1109/TIA.1984.4504578.

[3] S. Mantero, A. Monti, and S. Spreafico, "DC-bus voltage control for double star asynchronous fed drive under fault conditions," in Proc. IEEE Power Electronics Specialist Conference, Galway, vol. 1, 2000, pp. 533-538, doi: 10.1109/PESC.2000.878920.

[4] M. Steiner, R. Deplazes, and H. Stemmler, "A new transformerless topology for AC-fed traction vehicles using multi-star induction motors," EPE Journal, vol. 10, no. 3-4, pp. 45-53, Oct. 2000, doi: 10.1080/09398368.2000.11463469.

[5] Y. Burkhardt, A. Spagnolo, P. Lucas, M. Zavesky, and P. Brockerhoff, "Design and analysis of a highly integrated 9-phase drive train for EV applications," in Proc. IEEE International Conference on Electrical Machine (ICEM), 2014, pp. 450-456, doi: 10.1109/ICELMACH.2014.6960219.

[6] C. Bassi, A. Tessarolo, R. Menis, and G. Sulligoi, "Analysis of different system design solutions for a high-power ship propulsion synchronous motor drive with multiple PWM converters," in Electrical Systems for Aircraft Railway and Ship Propulsion (ESARS), 2010, pp. 1-6, doi: 10.1109/ESARS.2010.5665224.

[7] S. Castellan, R. Menis, M. Pigani, G. Sulligoi, and A. Tessarolo, "Modeling and simulation of electric propulsion systems for all-electric cruise liners," in IEEE ESTS, Arlington, 2007, pp. 60-64, doi: 10.1109/ESTS.2007.372064.

[8] A. Tessarolo, G. Zocco, and C. Tonello, "Design and testing of a 45-MW 100-Hz quadruple-star synchronous motor for a liquefied natural gas turbo-compressor drive," IEEE Trans. Ind. Appl., vol. 47, no. 3, pp. 1210-1219, 2011, doi: 10.1109/TIA.2011.2126036.

[9] J. Simond, A. Sapin, T. Xuan, R. Wetter, and P. Burmeister, "12-pulse LCI synchronous drive for a 20 MW compressor modeling, simulation and measurements," Fourtieth IAS Annual Meeting. Conference Record of the 2005 Industry Applications Conference, 2005, vol. 4, 2005, pp. 2302-2308, doi: 10.1109/IAS.2005.1518781.

[10] E. Jung, H. Yoo, S. Sul, H. Choi, and Y. Choi, "A Nine-Phase Permanent-Magnet Motor Drive System for an Ultrahigh-Speed Elevator," in IEEE Transactions on Industry Applications, vol. 48, no. 3, pp. 987-995, 2012, doi: 10.1109/TIA.2012.2190472.

[11] C. Sun, S. Ai, L. Hu, and Y. Chen, "The development of a 20MW PWM driver for advanced fifteen-phase propulsion induction motors," Journal of Power Electronics, vol. 15, no. 1, pp. 146-159, Jan. 2015, doi: 10.6113/JPE.2015.15.1.146.

[12] R. R. Bastos, T. S. de Souza, M. M. de Carvalho, L. A. R. Silva, and B. J. C. Filho, "Assessment of a Nine-Phase Induction Motor Drive for Metal Industry Applications,” in IEEE Transactions on Industry Applications, vol. 56, no. 6, pp. 7217-7226, Nov.-Dec. 2020, doi: 10.1109/TIA.2020.3023061.

[13] H. A. Toliyat, T. A. Lipo, and J. C. White, "Analysis of a concentrated winding induction machine for adjustable speed drive applications. II. Motor design and performance," in IEEE Transactions on Energy Conversion, vol. 6, no. 4, pp. 684-692, Dec. 1991, doi: 10.1109/60.103642.

[14] E. Levi, R. Bojoi, F. Profumo, H.A. Toliyat, and S. Williamson, "Multi-phase induction motor drives-a technology status review," IET Elect. Power Appl., vol. 1, no. 4, pp. 489-516, Aug. 2007, doi: 10.1049/iet-epa:20060342.

[15] E. A. Klingshirn, "High Phase Order Induction Motors-Part I-Description and Theoretical Considerations," in IEEE Transactions on Power Apparatus and Systems, vol. PAS-102, no. 1, pp. 47-53, Jan. 1983, doi: 10.1109/TPAS.1983.317996

[16] R. H. Nelson and P. C. Krause, "Induction Machine Analysis for Arbitrary Displacement Between Multiple Winding Sets," in IEEE Transactions on Power Apparatus and Systems, vol. PAS-93, no. 3, pp. 841-848, May 1974, doi: 10.1109/TPAS.1974.293983.

[17] M. L. Gasperi, "Life prediction modeling of bus capacitors in AC variable frequency drives," Conference Record of 2005 Annual Pulp and Paper Industry Technical Conference, 2005., 2005, pp. 141-146, doi: 10.1109/PAPCON.2005.1502060.

[18] B. P. McGrath and D. G. Holmes, "A general analytical method for calculating inverter DC-link current harmonics," IEEE Trans. Ind. Appl., vol. 45, no. 5, pp. 1851-1859, Sept./Oct. 2009, doi: 10.1109/TIA.2009.2027556.

[19] H. Wang and F. Blaabjerg, "Reliability of capacitors for DC-link applications in power electronic converters-an overview," IEEE Trans. Ind. Appl., vol. 50, no. 5, pp. 3569-3578, Sept./Oct. 2014, doi: 10.1109/TIA.2014.2308357.

[20] L. Shao et al.," Investigation on phase shift between multiple multiphase windings in flux-switching permanent magnet machines," IEEE Trans. Ind. App., vol. 53, no. 3, pp. 1958-1970, Jun. 2017, doi: 10.1109/TIA.2017.2664718.

[21] M. Slunjski, O. Dordevic, M. Jones, and E. Levi, "Symmetrical/asymmetrical winding reconfiguration in multiphase machines," IEEE Access, vol. 8, pp. 12835-12844, Jan. 2020, doi: 10.1109/ACCESS.2020.2965652.

[22] Y. Sun, W. Zhao, J. Ji, J. Zheng, and Y. Cheng, "Torque improvement in dual m-phase permanent-magnet machines by phase shift for electric ship applications," IEEE Trans. Vehicular Technology, vol. 69, no. 9, pp. 9601-9612, Sep. 2020, doi: 10.1109/TVT.2020.3004161.

[23] J. Paredes, B. Prieto, M. Satrústegui, I. Elósegui, and P. González, "Improving the performance of a 1 MW induction machine by optimally shifting from a 3-phase to a 6-phase machine design by rearranging the coil connections," in IEEE Trans. Ind. Electron., vol. 68, no. 2, pp. 1035-1045, Feb. 2021, doi: 10.1109/TIE.2020.2969099.

[24] E. Yolacan, M. K. Guven, M. Aydin, and A. M. El-Refaie, "Modeling and Experimental Verification of an Unconventional 9-Phase Asymmetric Winding PM Motor Dedicated to Electric Traction Applications," in IEEE Access, vol. 8, pp. 70182-70192, 2020, doi: 10.1109/ACCESS.2020.2985669.

[25] M. Onsal, Y. Demir, and M. Aydin, "A New Nine-Phase Permanent Magnet Synchronous Motor with Consequent Pole Rotor for High-Power Traction Applications," in IEEE Transactions on Magnetics, vol. 53, no. 11, pp. 1-6, Nov. 2017, Art no. 8700606, doi: 10.1109/TMAG.2017.2709788.

[26] Y. Demir, E. Yolacan, A. M. EL-Refaie, and M. Aydin, "Investigation of Different Winding Configurations and Displacements of a Nine-Phase Permanent-Magnet-Synchronous Motor with Unbalanced AC Winding Structure," in IEEE Transactions on Industry Applications, vol. 55, no. 4, pp. 3660-3670, July-Aug. 2019, doi: 10.1109/TIA.2019.2913156.

[27] R. Bojoi, F. Profumo and A. Tenconi, "Digital synchronous frame current regulation for dual three-phase induction motor drives," IEEE 34th Annual Conference on Power Electronics Specialist, 2003. PESC '03., 2003, vol. 3, 2003, pp. 1475-1480, doi: 10.1109/PESC.2003.1216804.

[28] G. K. Singh, K. Nam, and S. K. Lim, "A simple indirect field-oriented control scheme for multiphase induction machine," in IEEE Transactions on Industrial Electronics, vol. 52, no. 4, pp. 1177-1184, Aug. 2005, doi: 10.1109/TIE.2005.851593.

[29] L. De Camillis, M. Matuonto, A. Monti, and A. Vignati, "Optimizing current control performance in double winding asynchronous motors in large power inverter drives,” in IEEE Transactions on Power Electronics, vol. 16, no. 5, pp. 676-685, Sept. 2001, doi: 10.1109/63.949500.

[30] Y. Zhao and T. A. Lipo, "Space vector PWM control of dual three-phase induction machine using vector space decomposition," in IEEE Transactions on Industry Applications, vol. 31, no. 5, pp. 1100-1109, Sept.-Oct. 1995, doi: 10.1109/28.464525. 
[31] M. A. Abbas, R. Christen, and T. M. Jahns, "Six-Phase Voltage Source Inverter Driven Induction Motor," in IEEE Transactions on Industry Applications, vol. IA-20, no. 5, pp. 1251-1259, Sept. 1984, doi: 10.1109/TIA.1984.4504591.

[32] D. Hadiouche, H. Razik, and A. Rezzoug, "Study and simulation of space vector PWM control of double-star induction motors," 7th IEEE International Power Electronics Congress. Technical Proceedings. CIEP 2000 (Cat. No.00TH8529), 2000, pp. 42-47, doi: 10.1109/CIEP.2000.891389.

[33] A. Tessarolo, "On the modeling of poly-phase electric machines through Vector-Space Decomposition: Theoretical considerations," 2009 International Conference on Power Engineering, Energy and Electrical Drives, 2009, pp. 519-523, doi: 10.1109/POWERENG.2009.4915234.

[34] A. Tessarolo, L. Branz, and M. Bortolozzi, "Stator inductance matrix diagonalization algorithms for different multi-phase winding schemes of round-rotor electric machines part I. theory," IEEE EUROCON 2015-International Conference on Computer as a Tool (EUROCON), 2015, pp. 1-6, doi: 10.1109/EUROCON.2015.7313776.

[35] A. Muqorobin, A. Purwadi, and P. A. Dahono, "Output current ripple minimization of nine-phase PWM inverters," $20163 r d$ Conference on Power Engineering and Renewable Energy (ICPERE), 2016, pp. 105-111, doi: 10.1109/ICPERE.2016.7904845.

[36] E. A. Klingshirn, "Harmonic Filters for Six-Phase and Other Multiphase Motors on Voltage Source Inverters," in IEEE Transactions on Industry Applications, vol. IA-21, no. 3, pp. 588-594, May 1985, doi: 10.1109/TIA.1985.349714.

[37] E. E. Ward and H. Harer, "Preliminary investigation of an invertor-fed 5-phase induction motor," Proc. IEE, vol. 116, no. 6, pp. 980-984, June 1969, doi: 10.1049/piee.1969.0182.

[38] V. Kindl, R. Cermak, Z. Ferkova, and B. Skala, "Review of time and space harmonics in multi-phase induction machine," Energies, vol. 13, no. 496, p. 496, 2020, doi: 10.3390/en13020496.

[39] K. Gopakumar, V. T. Ranganthan, and S. R. Bhat, "Split-phase induction motor operation from PWM voltage source inverter," in IEEE Transactions on Industry Applications, vol. 29, no. 5, pp. 927-932, Sept.-Oct. 1993, doi: 10.1109/28.245716.

[40] K. Marouani, L. Baghli, D. Hadiouche, A. Kheloui, and A. Rezzoug, "A New PWM Strategy Based on a 24-Sector Vector Space Decomposition for a Six-Phase VSI-Fed Dual Stator Induction Motor," in IEEE Transactions on Industrial Electronics, vol. 55, no. 5, pp. 1910-1920, May 2008, doi: 10.1109/TIE.2008.918486.

[41] D. Hadiouche, L. Baghli, and A. Rezzoug, "Space-vector PWM techniques for dual three-phase AC machine: analysis, performance evaluation, and DSP implementation," in IEEE Transactions on Industry Applications, vol. 42, no. 4, pp. 1112-1122, July-Aug. 2006, doi: 10.1109/TIA.2006.877737.

[42] D. Yazdani, S. A. Khajehoddin, A. Bakhshai, and G. Joos, "Full Utilization of the Inverter in Split-Phase Drives by Means of a Dual Three-Phase Space Vector Classification Algorithm," in IEEE Transactions on Industrial Electronics, vol. 56, no. 1, pp. 120-129, Jan. 2009, doi: 10.1109/TIE.2008.927405

[43] G. Grandi, G. Serra, and A. Tani, "Space Vector Modulation of a Six-Phase VSI based on three-phase decomposition," 2008 International Symposium on Power Electronics, Electrical Drives, Automation and Motion, 2008, pp. 674-679, doi: 10.1109/SPEEDHAM.2008.4581262.

[44] D. Glose and R. Kennel, "Continuous Space Vector Modulation for Symmetrical Six-Phase Drives," in IEEE Transactions on Power Electronics, vol. 31, no. 5, pp. 3837-3848, May 2016, doi: 10.1109/TPEL.2015.2456234.

[45] M. B. R. Correa, C. B. Jacobina, C. R. da Silva, A. M. N. Lima, and E. R. C. da Silva, "Vector and scalar modulation for six-phase voltage source inverters," IEEE 34th Annual Conference on Power Electronics Specialist, 2003. PESC '03., 2003, pp. 562-567 vol.2, doi: 10.1109/PESC.2003.1218117.

[46] R. Bojoi, A. Tenconi, F. Profumo, G. Griva, and D. Martinello, "Complete analysis and comparative study of digital modulation techniques for dual three-phase AC motor drives," 2002 IEEE 33rd Annual IEEE Power Electronics Specialists Conference. Proceedings (Cat. No.02CH37289), 2002, pp. 851-857 vol.2, doi: 10.1109/PSEC.2002.1022560.

[47] D. Dujic, G. Grandi, M. Jones, and E. Levi, "A Space Vector PWM Scheme for Multifrequency Output Voltage Generation with Multiphase Voltage-Source Inverters,” in IEEE Transactions on Industrial Electronics, vol. 55, no. 5, pp. 1943-1955, May 2008, doi: 10.1109/TIE.2008.918468.

[48] H.-M. Ryu, J.-H. Kim and S.-K. Sul, "Analysis of multiphase space vector pulse-width modulation based on multiple d-q spaces concept," in IEEE Transactions on Power Electronics, vol. 20, no. 6, pp. 1364-1371, Nov. 2005, doi: 10.1109/TPEL.2005.857551

[49] O. López, D. Dujic, M. Jones, F. D. Freijedo, J. Doval-Gandoy and E. Levi, "Multidimensional Two-Level Multiphase Space Vector PWM Algorithm and Its Comparison with Multifrequency Space Vector PWM Method," in IEEE Transactions on Industrial Electronics, vol. 58, no. 2, pp. 465-475, Feb. 2011, doi: 10.1109/TIE.2010.2047826.

[50] Z. Liu, Y. Li, and Z. Zheng, "A review of drive techniques for multiphase machines," in CES Transactions on Electrical Machines and Systems, vol. 2, no. 2, pp. 243-251, June 2018, doi: 10.30941/CESTEMS.2018.00030.

[51] D. Dujic, M. Jones, and E. Levi, "Analysis of Output Current Ripple rms in Multiphase Drives Using Space Vector Approach," in IEEE Transactions on Power Electronics, vol. 24, no. 8, pp. 1926-1938, Aug. 2009, doi: 10.1109/TPEL.2009.2017746.

[52] P. A. Dahono, "Analysis and minimization of output current ripple of multiphase PWM inverters," 2006 37th IEEE Power Electronics Specialists Conference, 2006, pp. 1-6, doi: 10.1109/pesc.2006.1712231.

[53] A. Iqbal, E. Levi, M. Jones, and S. N. Vukosavic, "Generalised sinusoidal PWM with harmonic injection for multi-phase VSIs," 2006 37th IEEE Power Electronics Specialists Conference, 2006, pp. 1-7, doi: 10.1109/pesc.2006.1712206.

[54] S. Williamson and S. Smith, "Pulsating torque and losses in multiphase induction machines," in IEEE Transactions on Industry Applications, vol. 39, no. 4, pp. 986-993, July-Aug. 2003, doi: 10.1109/TIA.2003.813722

[55] A. Boglietti, R. Bojoi, A. Cavagnino, and A. Tenconi, "Efficiency Analysis of PWM Inverter Fed Three-Phase and Dual Three-Phase High Frequency Induction Machines for Low/Medium Power Applications,” in IEEE Transactions on Industrial Electronics, vol. 55, no. 5, pp. 2015-2023, May 2008, doi: 10.1109/TIE.2008.918489.

[56] M. Vujacic, O. Dordevic, and G. Grandi, "Evaluation of DC-link voltage switching ripple in multiphase PWM voltage source inverters," IEEE Trans. Power Electron., vol. 35, no. 4, pp. 3478-3490, Apr. 2020, doi: 10.1109/TPEL.2019.2936429.

[57] A. Muqorobin, P. A. Dahono and A. Purwadi, "Analysis and minimization of output current ripple of inverter-fed six-phase AC motors," 2017 IEEE 12th International Conference on Power Electronics and Drive Systems (PEDS), 2017, pp. 831-836, doi: 10.1109/PEDS.2017.8289272.

[58] A. Muqorobin and P. A. Dahono, "Spectral Analysis of Output Current of PWM Inverter-Fed Multiple Three-Phase AC Motors," 2018 Conference on Power Engineering and Renewable Energy (ICPERE), 2018, pp. 1-8, doi: 10.1109/ICPERE.2018.8739716.

[59] P. A. Dahono, Y. Sato, and T. Kataoka, "Analysis and minimization of harmonics in the AC and DC sides of PWM inverters," IEEJ Transactions on Industry Applications, vol. 115, no. 5, pp. 553-562, 1995, doi: 10.1541/ieejias.115.553. 


\section{BIOGRAPHIES OF AUTHORS}
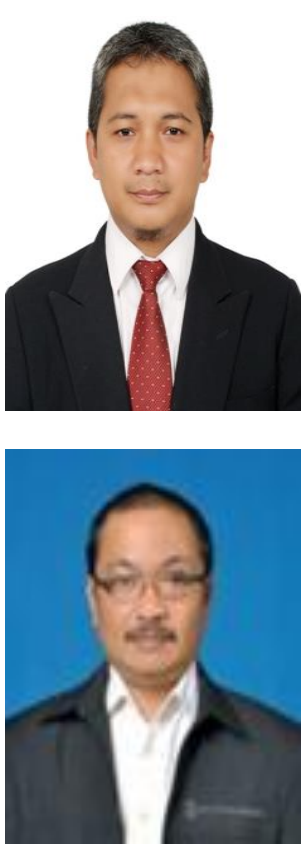

Anwar Muqorobin (D) If SC P received the bachelor degree from Universitas Diponegoro in 2001, the master degree from Institut Teknologi Bandung in 2013, and the doctor degree from Institut Teknologi Bandung in 2019, all in Electrical Engineering. He is currently a researcher at Research Center for Electrical Power and Mechatronics, Badan Riset dan Inovasi Nasional (BRIN). He has published several national and international papers. His research interest is inverter. Email: anwa014@brin.go.id.
Pekik Argo Dahono (D) 8I SC P got the Insinyur (Ir) degree from the Institut Teknologi Bandung, Indonesia in 1985, the Master and Doctor Engineering degrees from Tokyo Institute of Technology, Japan, in 1992 and 1995, respectively, all in electrical engineering. He is registered as a Professional Engineer in Indonesia and ASEAN. He is a senior member of IEEE. He is cofounder of Indonesia Smart Grid Initiatives and Indonesia Power Quality Initiatives. At present, he is a professor in the School of Electrical Engineering and Informatics, Institut Teknologi Bandung. He has interest in power electronics, power systems, and power quality. Email: pekik@konversi.ee.itb.ac.id. 